\title{
«ТРИ ОНТОЛОГІЧНІ ВИМІРИ ТІЛА» Ж.-П. САРТРА В КОНТЕКСТІ СОМАТИЧНОЇ ПРОБЛЕМАТИКИ СУЧАСНОГО ГУМАНІТАРНОГО ДИСКУРСУ
}

Актуальність теми дослідження зумовлена необхідністю всебічного аналізу всіх проявів персонального соматичного буття, його структурних змін і варіативності, визначення ролі тілесності в системі новітніх соціальних тенденцій.

Постановка проблеми. «Буття-для-другого» Сартра дозволяє зрозуміти не лише феномен свободи в його інтерпретації, але й закладає підвалини аналізу феномену Другого, центральне для постмодерної традиції, зокрема на прикладі проблеми ідентичності та теорії Іншого.

Аналіз останніх досліджень і публікацій. Суттєво вплинули на сучасне розуміння тілесності як культурної універсалії Е. Гуссерль, Ж. Лакан, М. Мерло-Понті, Ж.-П. Сартр, 3. Фрейд, представники сюрреалізму (Ж. Батай, А. Арто), французького постструктуралізму (Р. Барт, Ж. Дельоз, Ф. Гватарі, Ж. Бодрійяр, М. Фуко), а також М. Бахтін, Ю. Лотман і A. Лосєв.

Виділення недосліджених частин загальної проблеми. Важливим $\epsilon$ визначення особливості екзистенціального розуміння людини, особливо їі тілесних характеристик. Аналіз роботи «Буття і Ніщо» дає змогу вивчити теорію "буття для Другого», їі складові, з'ясувати три онтологічні прояви тіла і відносини з Другим як базові в фрілософрії Сартра.

Постановка завдання. Розкрити основні положення соматичної проблематики «теорії Другого» Ж.-П. Сартра, викладені в роботі "Буття і Ніщо» та дослідити подальшу трансформацію поняття Другий в його тілесних аспектах в контексті проблеми ідентичності.

Виклад основного матеріалу. Категорія Другого особлива, адже за ії допомогою Сартр пояснює буття людини. Відчужуючи здатності й можливості людини, другий робить можливим саморефллексію - людина (я) знаходить екзистенціальні стани (сорому, гордості, страху, нудоти) і пробує їх об'єктивувати знову. Об'єктивація, привласнення людиною ї̈ власних можливостей $і$ здатностей емпірично здійснюється відношенням тіл. Тіло другого, дозволяючи людині відкрити ії тіло, ніби організовує світ як певний порядок. Відтак, у Сартра тіло - і як моє, і як тіло другого - величина сенсоутворююча.

Ключові поняття: соматична проблематика; тіло; Ж.-П. Сартр; Другий; «буття-длядругого».

M. V. Olkhovyk, Candidate of Philosophical Sciences, Associate Professor

\section{J.-P. SARTRE'S “THREE ONTOLOGICAL DIMENSIONS OF THE BODY” IN THE CONTEXT OF SOMATIC PROBLEMS OF MODERN HUMANITARIAN DISCOURSE}

The urgency of the research resulted from the need for a comprehensive analysis of all dimensions of personal somatic existence, its structural changes and variability, possible transformations and functioning within the information society, and, consequently, determining the role of body in the latest social tendencies.

Target setting. The paper reveals the main aspects of somatic issues and the "theory of the body for the Other" suggested by J. P. Sartre in one of his main works "Being and Nothingness". To achieve this goal the theoretical and methodological foundations of somatic issues in the scientific discourse of the 20th - early 21st centuries have been studied.

Actual scientific researches and issues analysis. E. Husserl, J. Lacan, M. Merleau-Ponty, J. P. Sartre, Z. Freud, representatives of surrealism (J. Bataille, A. Arto), French poststructuralism (R. Barth, J. Deleuze, F. Guattari, J. Baudrillard, M. Foucault) and studies by M. Bakhtin, Y. Lotman, A. Losev had a significant influence on the understanding of the body as a cultural universal. 
Uninvestigated parts of general matters defining. Examining the originality of Sartre's ideas about the body and "body-for-the-Other", the peculiarities of the existential understanding of a man, especially his body characteristics, have been determined. The analysis of the work "Being and Nothingness" makes it possible to study the theory of "body-for-the-Other," its components, to clarify three ontological dimensions of the body and the relations with others as basic in Sartre's philosophy.

The research objective. To reveal the main aspects of the somatic problems of J.P. Sartre's "theory of the body for the Other", suggested by him in one of the major works "Being and Nothingness" and explore the further transformation of the concept of the Other in its bodily aspects in the context of the problem of identity.

The statement of basic materials. The category of the Other is peculiar because with its help Sartre explains the existence of a man. The existence of the Other must be recognized as an inviolable fact. And this is what allows a person to discover their own existence. As a result, a person finds themselves not as a subject who knows, but as a certain state (shame, pride, fear, nausea), as actual existence. And it is impossible to find this existence in oneself only by means of the Other. By alienating a person's abilities and capabilities, the other makes self-reflection possible - the person (I) finds these states and tries to objectify them again. Objectification, the appropriation of a person's own capabilities and abilities is empirically carried out by the relation of bodies. The body of the other, allowing the man to open his body, organizes the world in a certain order. Therefore, Sartre's body, both mine and the body of the other, is the value of meaning.

Conclusions. These studies laid the foundation for the tradition of analyzing the phenomenon of the Other, which has become central to the postmodern tradition. The paper reveals the features of the influence of the above ideas on the socio-cultural space, in particular on the example of the problem of identity and the theory of the Other.

Keywords: somatic problems; body; Sartre; the Other; body-for-the-other.

DOI: 10.25140/2412-1185-2019-2(14)-66-70

Актуальність теми дослідження. Сучасні уявлення про сутність тілесності, її значення в соціокультурних вимірах містять величезний обсяг інформації. Цілком закономірним $\epsilon$ перетворення феномену тілесності на універсальну категорію міждисциплінарного характеру. Необхідність всебічного аналізу соматичної проблематики у межах функціонування інформаційного суспільства робить актуальним визначення ролі тілесності в системі новітніх соціальних тенденцій.

Постановка проблеми. Рецепція теорії «буття-для-другого» уможливлює спробу накреслити методологічну перспективу її використання в сучасних галузевих дослідженнях. Адже «буттядля-другого» Сартра в своїх соматичних інтенціях може закладати підвалини аналізу, центральної для постмодерної традиції, теорії Іншого та проблеми ідентичності.

Аналіз останніх досліджень і публікацій. Процес "реабілітації" тілесності в європейській культурі XX ст., започаткований роботами Л. Фейєрбаха, А. Шопенгауера, Ф. Ніцше, породив великий пласт фрілософсько-естетичної літератури, присвяченої феномену тілесності.

Поворот до «нової тілесності» в культурі традиційно пов'язують з феноменологічною традицією, зокрема з роботами Е. Гусерля і М. Мерло-Понті, які не просто реабілітували концепт тіла, але розвернули антропологічну проблематику в бік персонального соматичного буття людини.

На розуміння тілесності як культурної універсалії вплинули Ж. Лакан, Ж.-П. Сартр, З. Фрейд, представники сюрреалізму (Ж. Батай, А. Арто), фрранцузького постструктуралізму (Р. Барт, Ж. Дельоз, Ф. Гватарі, Ж. Бодрійяр, М. Фуко), а також дослідження М. Бахтіна, Ю. Лотмана і А. Лосєва. Загальнотеоретичні питання тілесності проаналізовано в роботах І. Биховської, А. Гениса, Л. Жарова, С. Кримського, В. Круткіна, В. Подороги, Є. Причепія, В. Табачковського, В. Шинкарука, М. Ямпольського. Особливої уваги заслуговує вітчизняна фрілософськоантропологічна традиція, що сформувалась на початку двохтисячних (О. Гомілко, Л. Газнюк, Я. Потапенко, О. Багацька, Н. Хамітов).

Екзистенціальна філософрська традиція власне широко досліджена у вітчизняному i західному дискурсі: Т. Бабічева, О. Болльнов, П. Гайденко, Г. Гофмайстер, А. Дахній, К. Долгов, А. Зотов, М. Конох, С. Кримський, В. Кузнєцов, Н. Мотрошилова, К. Райда, Дж. Реале та 
Д. Антіс'єрі, В. Табачковський, Г. Тавризян та багато інших. Серед відомих вітчизняних дослідників філософії Ж.-П. Сартра слід згадати Ю. Беспечанського, А. Богачова, А. Дахнія, С. Іванову, В. Кебуладзе, С. Куцепал.

Виділення недосліджених раніше частин загальної проблеми. Соматична проблематика в контексті екзистенціальної фрілософрії унеможливлює виділення певної константи, в основному в силу диференційованості власне самого напрямку. Це ускладнює методологічне застосування цих теорій в сучасному дискурсі, зокрема тим, що соматичні інтенції релігійного екзистенціалізму, наприклад Г. Марселя або К. Ясперса, слабо корелюють з антропологічними пошуками М. Гайдеггера і Ж.-П. Сартра.

Постановка завдання. Дослідити своєрідність соматичної проблематики «теорії Другого» Ж.-П. Сартра та накреслити можливу трансформацію поняття Другий в його тілесних аспектах в контексті сучасної проблеми ідентичності.

Виклад основного матеріалу. Метафізика Сартра створювалась в ході переборення двох стратегій в онтології та антропології: позитивістського тлумачення людини як частини природи і спіритуалізму, що розчиняє буття людини в системі ідей. Звідси дві основні стратегії метафізики філософра: антиречовість і антиплатонізм. Заперечуючи позитивістський редукціонізм, Сартр зводить психіку до нейрофізіологічних механізмів. Цьому присвячені його роботи «Уява» (1937), а в художньому плані - роман «Нудота». Антиплатонізм розглядається Сартром як засіб переборення головного недоліку попередньої метафізики - спроб звести буття до мислення («Буття і Ніщо», «Нудота»). Дослідники рахують це поворотом від гносеології до онтологізму. Для Сартра така переорієнтація гарантувала не лише отримати «оголене» буття людини буття, від котрого людина була відлучена в минулих фрілософріях, але й вихід до «істинного», 3 його точки зору, суб'єкту [1].

Для розуміння сартрівської теорії тіла та другого, потрібо зупинитися на його уявленнях про буття як таке. Буття, на думку фрілософа, $є$, перш за все, даний нашій свідомості феномен буття. В якості ж цього феномену буття виявляється даними нашій свідомості як сенс сущого. В свою чергу, сенс сущого розкривається нам як відношення двох не взаємодіючих сфер - буття-в-собі, яке завжди $€$ те, що воно $є$ і буття-для-себе, дорефлексивного cogito. Тобто Сартр пропонує розуміти буття як відношення буття феномену до буття свідомості. У той же час сам феномен буття виявляється даним нашій свідомості безпосередньо, тобто ми його завжди маємо 3 очевидністю «як є». Останнє завжди є позитивне, самодостатнє, самообумовлене. Буття, що дається нам як «є», виступає як необхідна умова всього сущого і носить в той же час позачасовий трансцендентний характер з одного боку, з іншого ж, іманентно нерозділено з усім сущим. Тому воно завжди не прозоре, його не можна спостерігати, бо воно не виноситься за дужки. Наявність буття як «є» передує будь-якому мисленню, усвідомленню мого Я як суб'єкту і виокремленню людиною об'єктів [Цит. за: 2, с.191].

Екзистенціальна фрілософія висуває антропологему універсального одиничного, розглядаючи людську сутність з точки зору неподільності окремого і загального. Так, в останній фундаментальній праці Ж.-П. Сартра про Г.Флобера, що іï вважають своєрідною антропологічною лабораторією філософр висуває наступні тези.

Вади та слабкості, отже певна невизначеність людини закладена в самій природі та виявляється в невизначеності ії думок, вчинків, дій. У екзистенціальній філософрії така невизначеність осмислюється як «буття-між» (С. К'єркегор), «анонімні сили» (К. Ясперс), «вислизання й абсурдність» (А. Камю), «бездоганність у бутті» (М. Гайдеггер) [3 , с.82].

Проблемі відношення тіла до свідомості завжди заважав той фракт, що тіло, перш за все, розглядається як певна річ, що існує за певними законами і може бути визначена із зовні, тоді як свідомість пізнається глибокою інтуїцією, властивою йому. «Насправді, якщо осягнув свою свідомість в ії абсолютній глибині засобами рефлексивних актів, я спроможусь поєднати з нею певний живий об'єкт, утворений нервовою системою, мозком, залозами, органами виділення, дихання і кровообігу, сама матерія яких може бути проаналізована хімічно в атомах водню, азоту, фосфору тощо, тоді я зустрінусь з непереборними труднощами; які витікають з того, що я намагаюсь поєднати свою свідомість не з моїм тілом, але з тілом інших» [Цит. за: 2, с.191].

Прояснення природи тіла передбачає, за Сартром, послідовний розгляд тіла як буття-длясебе і буття-для-другого, з тим, щоб не плутати їх. Світ завжди існує в певному відношенні до людини. Не можна висловити щось про світ узагалі, виносячи спостерігача-людину за дужки. 
А тіло людини є індивідуальність включення її у світ. Буття завжди зорієнтоване у просторі. Речі розташовуються навколо людини як навколо певного центру. Народження, раса, соціальний клас, національність, фрізіологічна структура, характер, минуле - все це як синтетична єдність буття людини є її тіло, як необхідна умова існування світу і як випадкова реалізація цієї умови. Якщо тіло для-себе розглядається Сартром як центр відношення, позначений в порожнечі об'єктами - інструментами світу, або випадковістю, яка існує для-себе, то тіло як тіло-длядругого Сартр описує як таке, що існує в зовсім іншій площині реальності.

У контексті соматичної проблематики Сартр показує дві принципові позиції в інтерпретації свободи (моральної та імморальної). Особливе місце в концепції свободи, яку розуміють як тривогу, займає акцентування фрактору тілесності в розумінні сутності людського буття. Сартр намагається наповнити поняття свободи соматичним змістом.

I саме тривога має такі ознаки, адже в ній свобода отримую соматичний зміст, але зберігаючи інтелігібельний характер. Буття криється в свідомості, поглинається ним, трансформуючи в об'єкт, яким він не є. «Речі - це згустки буття-в-собі... Тіло - це згусток фактичності» [Цит за: 4]. Відтак, тіло - це не об’єкт, тіло - це онтологічний статус волі. Тіло перетворюється в дискурс.

Сам філософ підсумовує свої соматичні пошуки тезою про три отнологічні виміри тілесності. Те, що «людина існує своїм тілом - це її перший вимір буття. Тіло використовується і пізнається іншим - це його другий вимір буття. Оскільки я є для другого, він розкривається в людині як суб'єкт, для котрого я - об'єкт. Мова, перш за все, про фундаментальне відношення людини 3 іншим. Як висновок, я існує для себе як пізнаний другим, зокрема, у власній фрактичності. Я існує для себе як пізнаний другим в якості тіла. Це третій онтологічний вимір мого тіла [5, с. 371].

Висновки. Досліджуючи своєрідність сартрівських ідей щодо тіла та «буття для другого», визначено особливості екзистенціального розуміння людини, особливо ії тілесних характеристик. Категорія Другого особлива, адже за її допомогою Сартр пояснює буття людини, саме присутність Другого створює спільне буття, що несе подвійну детермінацію, бо залежить від обох. Власне існування можливе за умови існування Другого, коли людина усвідомлює себе як певний стан по відношенню до нього. Саморефлексія як момент знаходження своїх станів і спроба їх об'єктивувати. Тіло виконує роль засобу в цій об'єктивації, привласненні людиною її власних можливостей. Через тіло Другого, людина відкриває власне, тим самим організовуючи свій світ.

Постмодерний дискурс засвідчив певні зсуви антропологічної проблематики у бік проблеми ідентичності. Сучасні соціокультурні реалії, фрормування інформаційного суспільства, пошуки нових аксіологічних орієнтирів, пошуки нових фооматів самоусвідомлення у віртуальному просторі актуалізували проблему ідентичності в системі координат «Я/Інший» через поняття «тотожність/відмінність».

Постмодерна теза про важливість зустрічі власних уявлень про себе із сприйняттям нас оточуючими (Т. Еріксен) набуває нових відтінків з огляду на те, яка картинка нас самих формується сучасним соціокультурним простором, що $є$ в більшості своїй медійним, які технології для цього використовуються і, головне, яка мета при цьому переслідується (мова йде про те, як змінюються деякі наші ідентичності стосовно того, який образ спів-творюють сучасні медіа. Більш того, які тоді ідентичності фрормуються як імперативні (нав'язані), а які обираються вільно (нпр., патріотизм)).

У такому ракурсі особливого статусу набуває теорія «буття-для-другого», яка, корелюючи 3 особистістю, отримує нового функціонального забарвлення в контексті ідентичності та поняття «Іншого», особливо у координатах «ідентичності як відмінності». На перший план виступають взаємостосунки між ідентичністю та Іншим в сучасному соціумі. Для людини характерним стає не просто бачення власної тотожності чи відмінності з Іншим, а головним стає процес насолоди (у широкому сенсі слова) засобами Іншого (нпр., перенесення власної віри на іншого - «суб’єкт, можливо,віруючий»)

Наукове і практичне застосування результатів цього дослідження, на нашу думку, полягає у необхідності методологічного використання теорії «буття-для-другого», особливо соматичних положень, при аналізі сучасних соціальних комунікацій. Теза про тіло Другого як рівнозначне уявленням людини про сприйняття власного тіло Другим, отже погляд на себе очима іншого, 
тобто як на об'єкт, дає широкі можливості для розуміння і фрормування «образу тіла» в сучасному галузевому дискурсі.

Перспективним для подальшого дослідження можуть бути як глибокі прочитання сартрівської спадщини з використанням сучасних методологічних розробок фрілософської антропології, так і спроби поглиблення його теорії «буття-для-другого» в світлі проблеми «фрагментарної / втраченої ідентичності» в сучасному інформаційному суспільстві.

1. Лифинцева, Т. Жан-Поль Сартр: преследующий Бытие [Электронный ресурс] / Т. Лифинцева. - Режим доступу: https://postnauka.ru/faq/80430.

2. Чачанидзе, Г. Д. Проблема телесности в философии Ж.-П. Сартра / Г. Д. Чачанидзе // Сумма философии. Вып. 6. - Екатеринбург: Изд-во Урал. ун-та, 2006. - С. 190-195.

3. Косак, В. А. Людина та ії тілесність у різних формах культури: навчальний посібник / В. А. Косак. - Суми : Університетська книга, 2010. - 318 с.

4. Тревога как тело свободы в экзистенциализме Ж. П. Сартра [Электронный ресурс]. - Режим доступу: https://cyberleninka.ru/article/n/trevoga-kak-telo-svobody-v-ekzistentsializme-zh-p-sartra.

5. Сартр, Ж.-П. Буття і ніщо: нарис феноменологічної онтології [Электронный ресурс] / Жан-Поль Сартр. - К. : Видавництво Соломії Павличко “Основи”, 2001. - 854 с. - Режим доступу: https://www.livelib.ru/book/1001438847buttya-i-nischo-naris-fenomenologichnoyi-ontologiyi-zhanpol-sartr.

6. Сартр, Ж.-П. Экзистенциализм - это гуманизм / Ж.-П. Сартр // Сумерки богов. - М. : Политиздат, 1990. -398 с.

7. Соловьев, Э. Ю. Экзистенциализм (историко-критический очерк) [Електронний ресурс] / Э. Ю. Соловьев // Вопросы филлософии. - 1966. - №3; 1967. - №1. - Режим доступу: http://vphil.ru/index.php?option=com_content\&task $=$ view $\&$ id $=176 \&$ Itemid $=55$.

8. Людина в есенційних і екзистенційних вимірах / відп. ред. В. Табачковський. - К. : Наукова думка, 2004. - 246 с.

\section{Reference}

1. Lifintceva, T. (2017). Zhan-Pol Sartr: presleduyushhii Bytie [Jean-Paul Sartre: Pursuing Being]. postnauka.ru. Retrieved from https://postnauka.ru/faq/80430 [in Russian].

2. Chachanidze, G. D. (2006). Problema telesnosti v filosofii Zh.-P. Sartra [The problem of corporeality in the philosophy of J.-P. Sartre]. Summa filosofii - The sum of philosophy, 6, 190-195 [in Russian].

3. Kosak, V. A. (2010). Liudyna ta yii tilesnist u riznykh formakh kultury [Human and his corporeality in various forms of culture]. Sumy: Universytetska knyha [in Ukrainian].

4. Trevoga kak telo svobody $v$ ekzistentsializme Zh.P. Sartra [Anxiety as a body of freedom in the existentialism of J. P. Sartre]. cyberleninka.ru. Retrieved from https://cyberleninka.ru/article/n/trevoga-kak-telo-svobody-v-ekzistentsializme-zhp-sartra [in Russian].

5. Sartre, J.-P. (2001). Buttia i nishcho: narys fenomenolohichnoi ontolohii [Being and nothing: an essay on phenomenological ontology]. Kyiv: Vydavnytstvo Solomii Pavlychko "Osnovy". Retrieved from https://www.livelib.ru/book/1001438847-buttya-i-nischo-naris-fenomenologichnoyi-ontologiyi-zhanpol-sartr [in Ukrainian].

6. Sartre, J.-P. (1990). Ekzistentsializm - eto gumanizm [Existentialism is Humanism]. Sumerki bogov -Twilight of the Gods. (pp. 319-344). Moscow: Politizdat [in Russian].

7. Solovev, E. Yu. (2010). Ekzistentsializm (1966, № 3; 1967, № 1) (istoriko-kriticheskiy ocherk) [Existentialism (1966, № 3; 1967, № 1) (historical and critical essay)]. Voprosy filosofii - Philosophy issues. Retrieved from http://vphil.ru/index.php?option=com_content\&task=view\&id=176\&ltemid=55 [in Russian].

8. Tabachkovskyi, V. (Ed.). (2004). Liudyna $v$ esentsiinykh iekzystentsiinykh vymirakh [Human in essential and existential dimensions]. Kyiv: Naukova dumka [in Ukrainian]

Надійшла 23.10.2019

Бібліографрічний опис для цитування:

Ольховик, М. В. «Три онтологічні виміри тіла» Ж. П. Сартра в контексті соматичної проблематики сучасного гуманітарного дискурсу / М. В. Ольховик // Проблеми соціальної роботи: філософрія, психологія, соціологія. - 2019. - № 2 (14). - C. 66-70. 